\title{
SEBARAN RUMPON PESISIR PADA DAERAH PENANGKAPAN PURSE SEINE DI PERAIRAN DESA URENG KECAMATAN LEIHITU, KABUPATEN MALUKU TENGAH
}

\section{FISH AGGREGATING DEVICES (FAD) DISTRIBUTION AT PURSE SEINE FISHING GROUND IN THE WATERS OF URENG VILLAGE OLEIHITU DISTRICT, CENTRAL MALUKU REGENCY}

\author{
Muhidin Syamsuddin ${ }^{1}$, Deni Sarianto ${ }^{{ }^{*}}$, Djalaludin Kemhay ${ }^{1}$, Adnal Yeka ${ }^{2}$ \\ ${ }^{1}$ Program Pendidikan Perikanan Tangkap, Politeknik Kelautan dan Perikanan Maluku \\ ${ }^{2}$ Program Pendidikan Perikanan Tangkap, Politeknik Kelautan dan Perikanan Pariaman \\ *Korespondensi: denisarianto45@gmail.com
}

\begin{abstract}
The Fish Aggregating Devices (FADs) have been utilized for a long time by the purse seine fishermen in Ureng. This research was aimed at mapping the devices operating by Ureng fishermen and indentifying the dominant captured fish surrounding the set devices. This research was conducted in Lihitu district, Central Maluku Regency. The results showed that there was one large circle that resembled a ball with several groups of five small circles inside. Based on the type, the dominant fish caught around the FADs were mackerel (45 ton), mackerel tuna (25 ton), and skipjack tuna (20 ton). Overall, this study found that the catch using the purse seine in the five FAD groups was dominated by small and medium sized fish. In conclusion, under the potential fishing area for purse saine fishermen in Ureng, if the distance between the FADs is adjusted, fish are not trapped forever in the FADs and can migrate, lay eggs in other areas outside the waters of Ureng.
\end{abstract}

Keyword: FADs, purse seine, fishing ground

\section{Pendahuluan}

Maluku Tengah merupakan salah satu Kabupaten yang terdapat di Provinsi Maluku. Kabupaten ini sebagian wilayah administrasinya berada di Pulau Ambon. Kecamatan Leihitu merupakan bagian dari Kabupaten Maluku Tengah yang merupakan salah satu daerah penghasil perikanan terbesar di Pulau Ambon. Sentral perikanan di Leihitu berada pada desa Ureng, dimana pada desa Ureng terdapat perusahan yang menjadi pengumpul hasil perikanan. Sehingga menjadikan desa Ureng menjadi salah satu penggerak perekonomian wilayah Leihitu. Menurut data statistik KKP (2017) potensi perikanan di Wilayah Pengelolaan Perikanan Republik Indonesia (WPPRI) 714 yang tercatat di Badan Pusat Statistik (BPS) Maluku Tengah sebesar $130.538,4$ ton/tahun.

Rumpon atau Fish Aggregating Devices (FADs) merupakan alat bantu dalam kegiatan penangkapan ikan yang digunakan nelayan tangkap desa Ureng dalam mengumpulkan ikan sehingga lebih mudah untuk ditangkap. Rumpon adalah alat bantu dalam pengumpul ikan yang menggunakan berbagai bentuk dan jenis pengikat/atraktor 
dari benda padat, berfungsi untuk memikat ikan agar berkumpul, yang dimanfaatkan untuk meningkatkan efisiensi dan efektifitas operasi penangkapan ikan (KKP, 2014). Alat tangkap yang digunakan untuk menangkap ikan di sekitar rumpon tersebut yaitu pukat cincin (purse seine) dan pancing ulur. Pertambahan jumlah rumpon yang dipasang oleh nelayan Ureng sangat pesat. Bertambahnya penggunaan rumpon meningkatkan produktivitas penangkapan, sehingga memungkinkan para pemilik kapal/masyarakat pesisir untuk menambah/ membuat kapal dalam rangka meningkatkan eksploitasi terhadap sumber daya ikan yang ada (Nurdin, 2014 dalam Sarianto \& Istrianto, 2019).

Keberadaan rumpon di suatu perairan mampu memicu terbentuknya daerah penangkapan ikan (DPI) baru yang potensial di perairan. Rumpon mampu menarik berkumpulnya biomassa ikan dalam jumlah besar di sekitarnya. Meningkatnya kepadatan ikan di sekitar rumpon dapat meningkatkan peluang suksesnya operasi penangkapan. Produksi ikan oleh kapal purse seine yang beroperasi di dekat rumpon $60 \%$ lebih banyak dibandingkan kapal yang mengejar gerombolan ikan tanpa rumpon. Rumpon terbukti mampu meningkatkan produksi ikan di suatu perairan, namun produktivitas penangkapan di sekitar rumpon juga dipengaruhi oleh bahan yang digunakan dalam pembuatan aktraktor. (Simbolon et al., 2011) menyatakan pengunaan rumpon alami memiliki produktivitas lebih tinggi dari pada rumpon sintetik sedangkan (Wudianto et al., 2017) menyatakan ketertariakan ikan tinggal di rumpon dalam waktu lama akan berpengaruh terhadap pertubuhan ikan.

Penggunaan rumpon sebagai alat bantu pengumpul ikan dalam kegiatan penangkapan ikan mampu meningkatkan produksi hasil tangkapan di Ureng. Produktivitas kapal-kapal purse seine dan pancing ulur di Ureng cukup tinggi, sehingga jumlah rumpon yang dipasang oleh nelayan bertambah jumlahnya dari waktu kewaktu semakin banyak. Namun demikian, tertangkapnya ikan yang belum dewasa dalam jumlah yang besar di sekitar rumpon dikhawatirkan dapat mengganggu keberlanjutan sumberdaya ikan yang ada. Penelitian ini bertujuan untuk: (1) memetakan rumpon yang dioperasikan nelayan Ureng di perairan; dan (2) jenis ikan yang ditangkap di sekitar rumpon.

\section{Bahan dan Metode}

Penelitian dilaksanakan di Desa Ureng Kecamatan Leihitu, Kabupaten Maluku Tengah, Propinsi Maluku. Waktu pengambilan data dilaksanakan pada tanggal 01 September - 21 November 2020. Gambaran mengenai kondisi di sekitar rumpon, metode pengoperasian alat tangkap, jenis ikan yang teramati di dekat rumpon dan jenis yang biasa tertangkap, diperoleh dari hasil pengamatan di kapal dan wawancara dengan 5 orang nakhoda dan 20 awak kapal purse seine yang melakukan penangkapan di Ureng. 


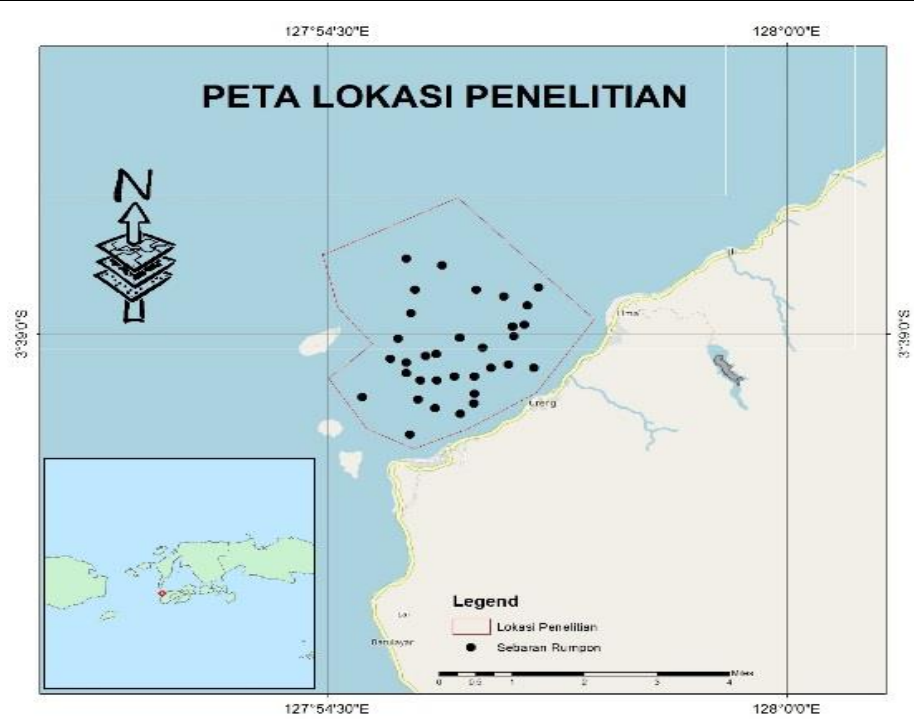

Gambar 1. Peta sebaran rumpon

Data mengenai jenis ikan yang tertangkap di sekitar rumpon pesisir diperoleh dari data hasil tangkapan kapal pukat purse seine yang menangkap ikan di sekitar rumpon yang didaratkan di perusahaan ikan dan pendaratan ikan pantai di Ureng. Data harian pendaratan ikan hasil tangkapan untuk menghitung produktivitas alat tangkap diperoleh dari armada tangkap dan dinas perikanan kabupaten Maluku Tengah. Penentuan sebaran rumpon berdasarkan data GPS yang diambil langsung pada tempat beradanya rumpon tersebut mengunakan GPS garmin 78s. Data posisi rumpon diolah dengan mengunakan software ArcGis 10.2 dan disajakan dalam bentuk gambar (Gambar 1). Jenis ikan di data mulai dari operasi penangkapan sampai pada saat pelelangan ikan. Penentuan jenis ikan diperoleh dari portal www.fishbase.org.

\section{Hasil dan Pembahasan Sebaran Rumpon}

Sebaran Rumpon dalam penelitian ini terbadi 5 kelompok yang menjadi pusat penyebaran rumpon sebagai berikut: (1) lingkaran rumpon 1 (Gambar 3); lingkaran rumpon 2 (Gambar 4); lingkaran rumpon 3 (Gambar 5); lingkaran rumpon 4 (Gambar 6); dan lingkaran rumpon 5 (Gambar 7).

Penyebaran rumpon di Ureng yang terkonsentasi pada satu wilayah disebabkan 2 faktor utama (Gambar 2). Pertama adalah faktor internal yang berasal dari armada penangkapan ikan tersebut berupa gross tonnage (GT). Ukuran armada penangkapan ikan yang menggunakan rumpon pesisir berukuran kurang dari 10 GT. Kedua adalah faktor ekternal yang berasal dari luar yaitu dekatnya tempat penjaualan hasil penangkapan ikan dimana di Ureng terdapat perusahan penampung hasil perikanan dan juragan-juragan pengepul hasil perikanan. Faktor lain seperti alam, angin, hujan dan gelombang tidak begitu berpengaruh terhadap aktifitas penangkapan ikan pada rumpon 
yang ada. (Nurdin et al., 2018) menyatakan factor oceonografi sangat berpengaruh terhadap hasil tangkapan di sekitar rumpon.

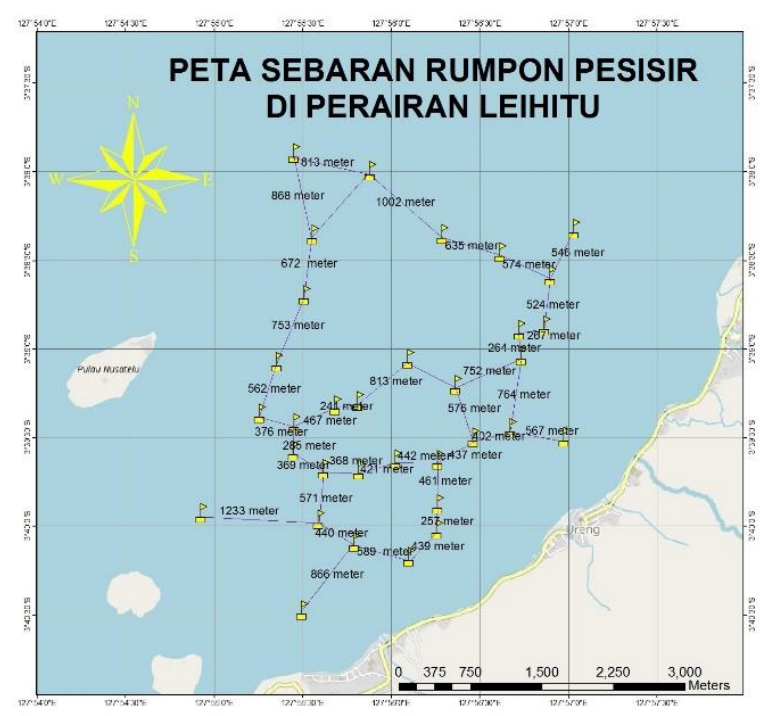

Gambar 2 Rumpon armada tangkap

Rumpon yang tersebar dan membentuk kelompok 1 merupakan rumpon yang menghadang ikan masuk dari arah pulau 3 (Asilulu) selanjutnya akan tertahan dan terjebak dalam lingkaran rumpon. Banyaknya pulau dan kuatnya sirkulasi air keluar masuk teluk membuat ikan merasa nyaman berada dalam kurungan rumpon. Kelompok rumpon 1 memiliki jarak antara 1 rumpon dengan rumpon yang lain berkisaran 257 meter sampai 1233 meter ( Gambar 3).

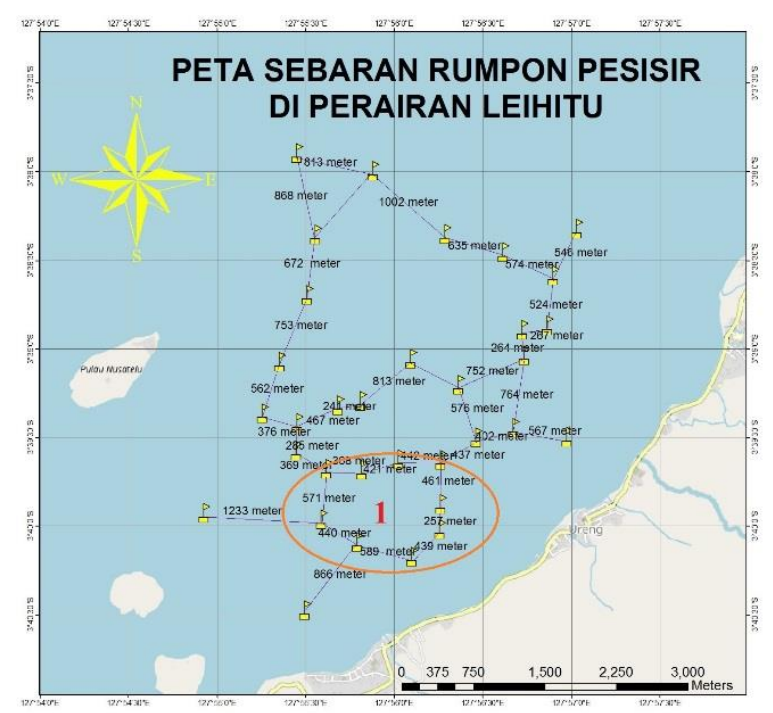

Gambar 3 Kelompok rumpon 1 armada tangkap 
Pada kelompok rumpon 2 jarak rumpon berkisaran antara 241 meter sampai 813 meter (Gambar 4). Rumpon ini berada persis di belakang rumpon 1 yang juga menghadang ikan masuk dari bagian lain dari arah Pulau Tiga yang merupakan daerah karang dan tempat keluar masuk arus laut menuju perairan pedalam pesisir Ureng dengan kepadatan rumpon lebih tinggi dari kelompok rumpon 1.

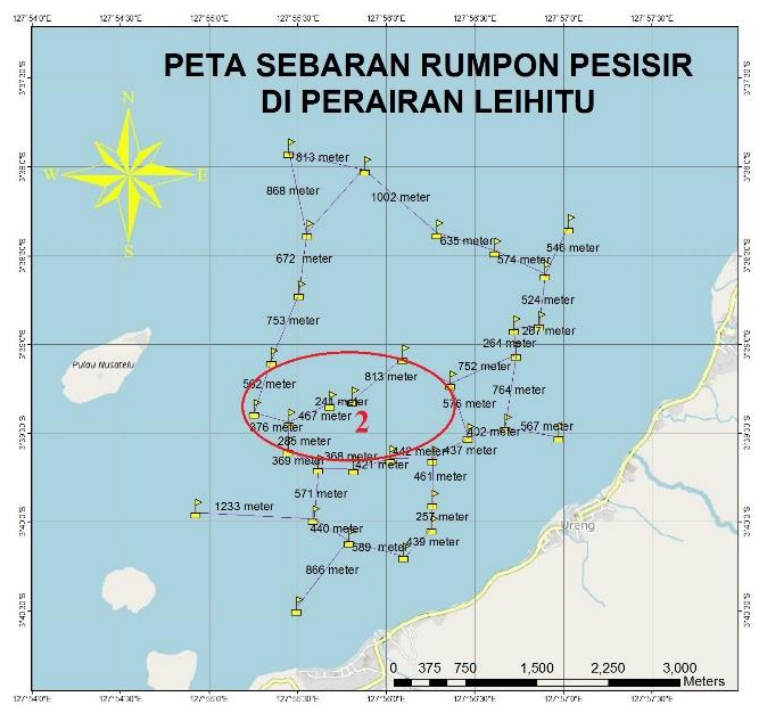

Gambar 4 Kelompok rumpon 2 armada tangkap

Persis di bagian samping kelompok rumpon 2 terdapat satu kelompok rumpon lagi yang keberadaannya lebih dekat ke pantai akan tetapi mempunyai jumlah rumpon lebih sedikit dari pada kelompok rumpon 1 dan kelompok rumpon 2. Kelompok rumpon 3 jarak rumpon berkisaran 264 meter sampai 752 meter. (Gambar 5)

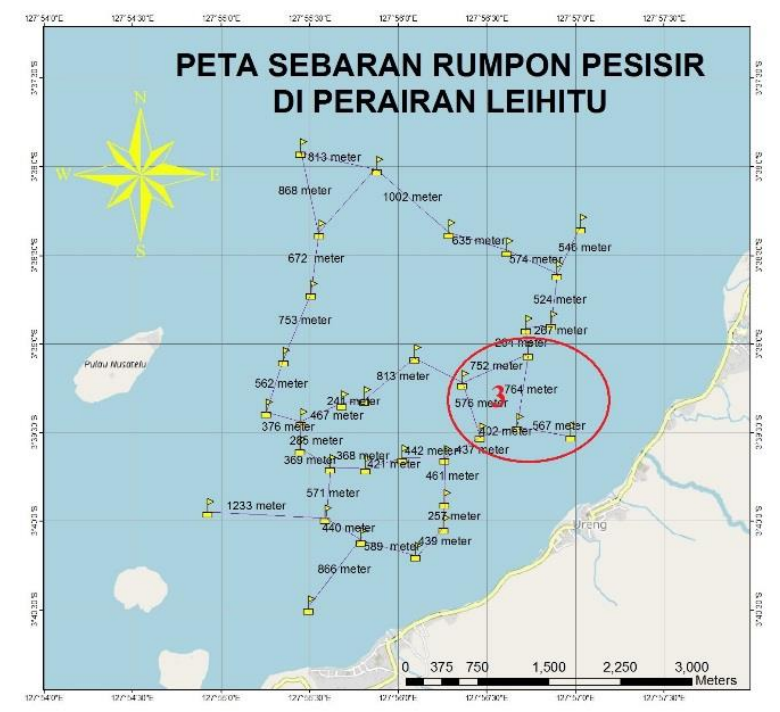

Gambar 5 Kelompok rumpon 3 armada tangkap 
Pada bagian perairan yang lebih luas berada dalam posisi menghadap Pulau Tiga serta Selat Kelang terdapat kelompok rumpon 4. Rumpon kelompok ini memiliki jarak antara satu rumpon dengan rumpon yang lain berjarak 542 meter sampai 672 meter dengan jumlah rumpon cukup banyak dan tersebar merata. (Gambar 6)

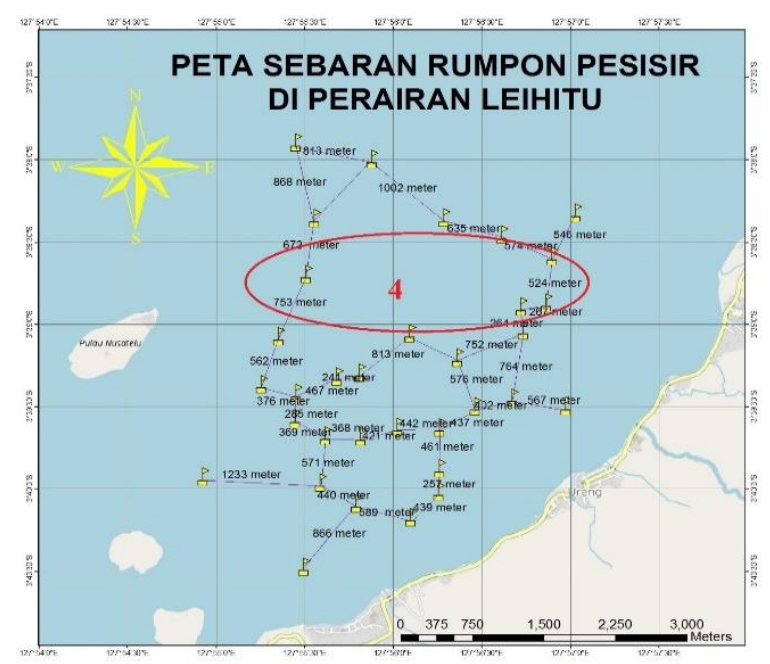

Gambar 6 Kelompok rumpon 4 armada tangkap

Bagian terjauh dan menghadap langsung Selat Kelang terdapat rumpon kelompok 5. Kelompok rumpon ini memiliki jumlah rumpon paling sedikit dari kelompok lain dan memiliki jarak yang cukup jauh dari kelompok rumpon yang ada. Jarak rumpon pada kelompok 5 berjarak 613 meter sampai 1002 meter. (Gambar 7)

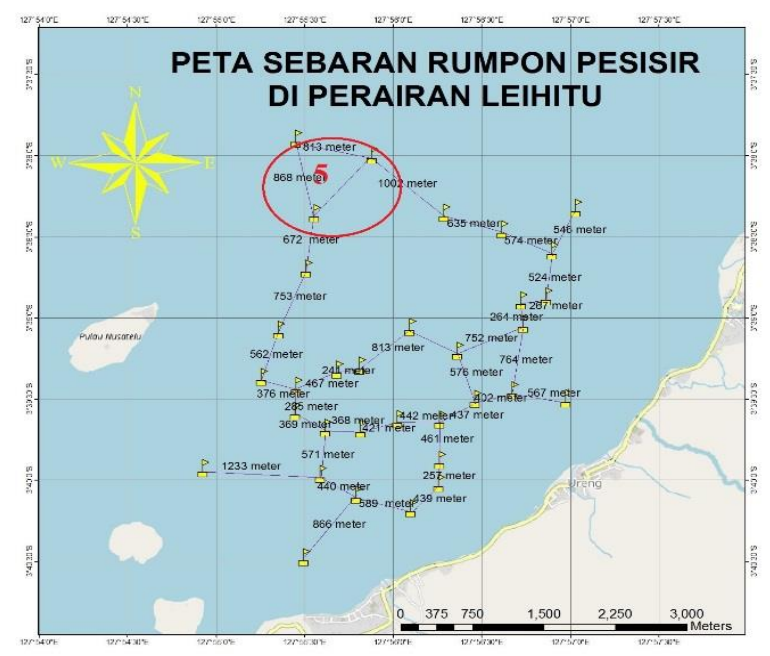

Gambar 7 Kelompok rumpon 5 armada tangkap

KPP (2011) menempatkan jalur penangkapan ikan pada WPPRI dibagi menjadi 3 jalur sebagai berikut: (1) Jalur penangkapan I meliputi perairan 2-4 mil laut, (2) Jalur penangkapan II meliputi perairan 4-12 mil laut, dan (3) Jalur penangkapan III meliputi 
Zona Ekonomi Eklusif Indonesia (ZEEI). Sedangkan Pasal 7 dan pasal 22 menjelaskan jalur penangkapan yang digunakan untuk pengoperasian purse seine. Armada kapal purse seine pelagis kecil yang berukuran kurang dari 10 GT memiliki tali ris atas kurang $300 \mathrm{~m}$. Talis ris atas yang panjang $400 \mathrm{~m}$, beroperasi pada jalur II dan III dengan ukuran kapal 10-30 GT. Sedangkan untuk kapal lebih besar dari 30 GT memiliki tali ris atas dibawah $600 \mathrm{~m}$. Armada kapal purse seine pelagis besar dengan kapal 10-30 GT memiliki panjang tali ris atas kurang dari $700 \mathrm{~m}$, sedangkan kapal yang berukuran diatas 30 GT memiliki tali ris atas kurang dari $1500 \mathrm{~m}$.

Rumpon yang berada di Ureng tersebar bererapa titik sentral yang meliliki jarak yang sangat padat dimana jarak antara satu rumpon kepada rumpon yang lain berjarak kurang dari 1 mil. Keberadaan rumpon di desa Ureng berbentuk seperti lingkaran besar dengan beberapa lingkaran kecil didalamnya. Rumpon yang berbentuk lingkaran akan membuat ikan terkurung di dalam dan malas untuk keluar dari rumpon tersebut. Berdasarkan hasil wawancara dengan nelayan di Ureng, mengatakan bahwa sekarang ini bisa ditemukan ikan tuna setiap hari, dimana sebelumnya ikan tuna disana hanya ditemukan pada bulan-bulan tertentu akan tetapi sekarang tidak lagi. Mengacu kepada aturan Permen KP No. 24 tahun 2014 tentang rumpon menyatakan bahwa rumpon di perairan berjarak paling dekat 10 mil, tidak boleh membentuk formasi zig zag dan tidak mengganggu alur pelayaran.

Rumpon pesisir yang berada di perairan leihitu/Ureng memiliki sebaran yang sangat padat. Banyaknya rumpon terdapat di perairan disebabkan oleh perairan lebih tenang dan mempunyai kedalaman yang relatif lebih dangkal. Hal ini disebabkan terdapatnya berapa pulau di depan desa Ureng yang menjadi pelindung dari kuatnya gelombang datang dari Laut Banda. Keadaan ini memberikan peluang yang besar bagi masyarakat nelayan dalam memiliki rumpon sendiri. Gelombang yang kecil di perairan antar kepulauan di sebabkan oleh keterbatasan tiupan angin sedangkan gelombang yang terbentuk pada lepas pantai mempunyai energi yang besar akibat besarnya tiupan angin ( Ganesa dalam Sarianto \& Istrianto, 2019).

\section{Jenis Ikan yang Tertangkap di Sekitar Rumpon Pesisir}

Jenis ikan yang berkumpul di sekitar rumpon yang dipasang oleh nelayan $\underline{\text { Ureng, }}$ meskipun tidak semuanya, dapat diketahui dari jenis ikan yang tertangkap oleh alat tangkap yang dioperasikan di sekitar rumpon tersebut, yaitu pukat cincin dan pancing ulur. Jenis ikan yang tertangkap menggunakan pukat cincin umumnya berupa ikan yang membentuk gerombolan (schooling) dan memiliki ketertarikan terhadap cahaya karena dalam pengoperasiannya pukat cincin menggunakan lampu untuk menarik ikan berkumpul sehingga mudah ditangkap. Ikan yang tertangkap menggunakan pancing ulur tidak selalu harus dalam keadaan bergerombol dan memiliki kedalaman renang hingga lebih dari 200 meter, khususnya untuk jenis ikan marlin dan tuna mata besar. Hasil identifikasi terhadap hasil tangkapan yang didaratkan di Ureng dan pengambilan 
contoh ikan di atas kapal pukat cincin dan pancing ulur menunjukkan adanya 17 spesies ikan yang tertangkap menggunakan kedua alat tangkap tersebut. Jenis ikan yang tertangkap di sekitar rumpon berasal dari 8 suku/famili yaitu: (1) Scombridae: cakalang (Katsuwonus pelamis), tuna sirip kuning (Thunnus albacares), albakora (Thunnus alalunga), tongkol (Euthynnus affinis), tuna mata besar (Thunnus obesus), tenggiri (Scomberomorus sp.) kembung (Rastrelliger sp.); (2) Carangidae: layang (Decapterus $s p$ ), kuwe (Caranx sexfasciatus), selar (Selaroides sp) ; (3) Coryphaenidae: lemadang (Coryphaena hippurus); (4) Istiophoridae: marlin (Makaira sp.); (5) Charcharinidae: hiu (Carcharhinus longimanus); (6) Monacanthidae: pogot (Canthidermis maculata); (7) Loliginidae: cumi-cumi (Loligo sp.); dan (8) Clupeidae: lemuru (Sardinella lemuru), dan tembang (Sardinella fimbri-ata).

Data produksi Ureng tahun 2020 pada bulan Oktober menunjukkan jenis ikan yang dominan tertangkap di sekitar rumpon (Gambar 8) yaitu layang (45 ton), tongkol (25 ton) dan cakalang (20 ton). Ikan jenis lain tertangkap dalam jumlah yang lebih sedikit, antara lain: kembung ( 9 ton), tuna mata besar (6 ton), selar ( 5 ton), albakora (4 ton), tembang (2.3 ton), lemuru ( 2 ton), cumi-cumi ( 1 ton), kuwe (0.9 ton). Jenis ikan yang lain tertangkap dalam jumlah yang sangat sedikit, yaitu lumadang $(0,8$ ton), tenggiri ( 0,4 ton), marlin ( 0,3 ton), hiu ( $0.0,1$ ton), pogot ( 0,01 ton).

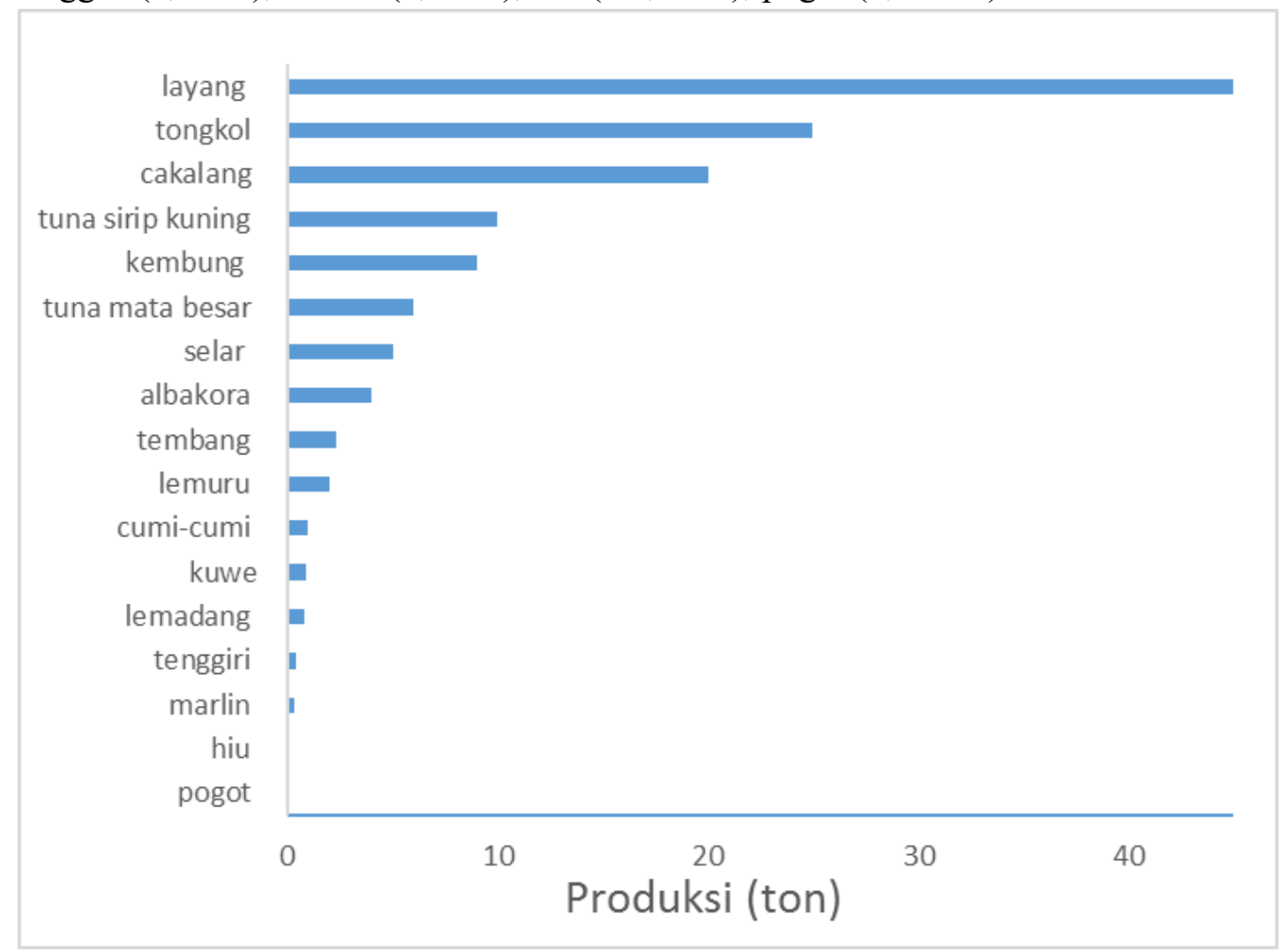

Gambar 8. Produksi berdasarkan jenis ikan yang tertangkap di Ureng bulan Oktober

Tahun 2020 
Ikan layang, cakalang, dan tongkol merupakan jenis ikan yang paling banyak di tangkap di sekitar rumpon. Besarnya produksi ketiga jenis ikan tersebut kemungkinan disebabkan oleh keberadaannya yang melimpah di Laut Banda, sifatnya yang senang berasosiasi dengan rumpon serta tingkah lakunya yang senang berenang secara bergerombol sehingga mudah untuk ditangkap menggunakan pukat Purse seine dalam jumlah besar.

Ikan layang tersebar hampir di seluruh perairan tropis dan sub tropis di dunia. Layang merupakan jenis ikan yang memiliki tingkat pertumbuhan dan perkembangbiakan yang cepat, sehingga dianggap mampu bertahan terhadap tekanan dari tingginya kegiatan penangkapan terhadap spesies tersebut. (Iksan, 2017) menyatakan adanya perbedaan laju pertembuhan suatu ikan disebabkan oleh pengaruh ketersediaan makanan, waktu pemijahan, serta waktu dan tekanan penangkapan yang berbeda.

Ikan layang biasa ditemukan di sekitar rumpon dalam gerombolan besar bersamaan dengan tongkol, kembung dan lain-lain dengan lama tinggal di satu rumpon berkisar antara 1 - 13 hari sebelum berpindah ke rumpon lain, tergantung pada faktor biotik eksternal yang ada seperti ketersediaan makanan, keberadaan pesaing sejenis atau keberadaan predator (Govinden et al., 2013).

Proporsi hasil tangkapan ikan layang, tongkol, dan cakalang lebih besar di sekitar rumpon. Sedangkan hasil tangkapan tuna madidihang di sekitar rumpon lebih kecil. Juvenil ikan tuna madidihang, biasanya didapati oleh nelayan berenang bergerombol di dekat permukaan dengan ikan cakalang yang memiliki ukuran yang hampir sama, sehingga ikut tertangkap oleh pukat purse seine. Tuna yang berukuran besar yang didaratkan di Ureng ditangkap oleh nelayan pancing ulur. Tuna yang berukuran besar berenang pada lapisan yang lebih dalam (Barata et al., 2011), sehingga lebih banyak tertangkap dengan menggunakan pancing ulur.

Ikan jenis lainnya tertangkap dalam jumlah kecil dan biasanya hanya dianggap sebagai hasil tangkapan sampingan. Kuwe, cumi-cumi, lemadang merupakan jenis yang paling umum didapati berasosiasi dengan rumpon (Simbolon et al., 2011) menyatakan benyaknya ikan yang berasioasi pada rumpon dipengaruhi oleh jenis bahan material penyusun rumpon. Nelayan Ureng mengunakan rumpon rakit dari bambu dan pelepah nipah yang dirangkai berlapis sehinga membantu meningkatkan terbentuknya organisme baru yang menjadi makanan ikan. Hasil tangkapan nelayan ureng untuk ikan tongkol, cakalang, kuwe memiliki ukuran kecil. Dimana ukuran ikan ini berukuran sama dengan ukuran ikan layang. Kuat dugaan ikan tongkol, cakalang dan layang yang berukuran kecil tertangkap bersama dengan gerombolan ikan kecil yang sejenis. 


\section{Kesimpulan dan Saran \\ Kesimpulan}

Rumpon yang di operasikan nelayan Ureng berada dalam kepadatan yang sudah melebihi kemampuang rumpon untuk berada dalam satu perairan. Kawasan ini merupakan daerah penangkapan yang potensial, akan tetapi sering dijumpai tertangkap ikan yang belum atau berukuran tidak layak tangkap untuk jenisnya. Hasil tangkapan utama nelayan ureng adalah ikan pelagis dimana layang, tongkol, cakalang, dan madidihang merupakan tangkapan utama. Penggunaan rumpon berdampak positif dalam meningkatkan peluang keberhasilan operasi penangkapan purse seine namun dapat menimbulkan dampak negatif berupa meningkatnya peluang tertangkapnya jenis dan ukuran ikan yang tidak layak tangkap (immature fish)

\section{Saran}

Perlu dilakukan pengelolaan yang lebih baik terhadap penggunaan rumpon oleh nelayan di Ureng. Pengaturan perizinan pemasangan rumpon dan jarak pemasangan antar rumpon perlu dilakukan untuk mempermudah pengawasan dan mencegah terganggunya alur migrasi ikan. Konversi alat tangkap purse seine dengan alat tangkap lain yang lebih ramah lingkungan seperti pancing ulur dan rawai tuna sebaiknya dilakukan, untuk mengurangi tertangkapnya ikan yang belum layak tangkap.

\section{Daftar Pustaka}

Barata, A., Novianto, D., \& Bahtiar, A. (2011). Sebaran ikan tuna berdasarkan suhu dan kedalaman di Samudera Hindia. Ilmu Kelautan: Indonesian Journal of Marine Sciences, 16(3), 165-170.

(DKP) Dinas Kelautan dan Perikanan Maluku Tengah. 2017. Laporan Statistik Perikanan Sibolga Tahun 2017. DKP Sibolga

Govinden, R., Jauhary, R., Filmalter, J., Forget, F., Soria, M., Adam, S., \& Dagorn, L. (2013). Movement behaviour of skipjack (Katsuwonus pelamis) and yellowfin (Thunnus albacares) tuna at anchored fish aggregating devices (FADs) in the Maldives, investigated by acoustic telemetry. Aquatic Living Resources, 26(1), 69-77.

Iksan, K. H. (2017). Pertumbuhan Dan Reproduksi Ikan Layang Biru (Decapterus Macarellus) Di Perairan Maluku Utara [Growth and Reproduction of Mackerel Scads, Decapterus Macarellus (Cuvier, 1833) in North Moluccas Waters]. Jurnal Iktiologi Indonesia, 9(2), 163-174.

Barata, A., Novianto, D., \& Bahtiar, A. (2011). Sebaran ikan tuna berdasarkan suhu dan kedalaman di Samudera Hindia. Ilmu Kelautan: Indonesian Journal of Marine Sciences, 16(3), 165-170.

(DKP) Dinas Kelautan dan Perikanan Maluku Tengah. 2017. Laporan Statistik Perikanan Sibolga Tahun 2017. DKP Sibolga 
Govinden, R., Jauhary, R., Filmalter, J., Forget, F., Soria, M., Adam, S., \& Dagorn, L. (2013). Movement behaviour of skipjack (Katsuwonus pelamis) and yellowfin (Thunnus albacares) tuna at anchored fish aggregating devices (FADs) in the Maldives, investigated by acoustic telemetry. Aquatic Living Resources, 26(1), 69-77.

Iksan, K. H. (2017). Pertumbuhan Dan Reproduksi Ikan Layang Biru (Decapterus Macarellus) Di Perairan Maluku Utara [Growth and Reproduction of Mackerel Scads, Decapterus Macarellus (Cuvier, 1833) in North Moluccas Waters]. Jurnal Iktiologi Indonesia, 9(2), 163-174.

[KKP] Kementerian Kelautan dan Perikanan. Peraturan Menteri Kelautan dan Perikanan Republik Indonesia Nomor 2/PERMEN-KP/2011 tentang Jalur Penangkapan Ikan Dan Penempatan Alat Penangkapan Ikan Dan Alat Bantu Penangkapan Ikan Di Wilayah Pengelolaan Perikanan Negara Republik Indonesia. [Internet]. [diunduh pada 5 Juni 2020]. Tersedia pada http://djpt.kkp.go.id.

[KKP] Kementerian Kelautan dan Perikanan. Peraturan Menteri Kelautan dan Perikanan Republik Indonesia Nomor 26/PERMEN-KP/2014 tentang Rumpon. [Internet]. [diunduh pada 5 Juni 2020]. Tersedia pada http://djpt.kkp.go.id.

Nurdin, E., Panggabean, A. S., \& Restiangsih, Y. H. (2018). Pengaruh Parameter Oseanografi Terhadap Hasil Tangkapan Armada Tonda di Sekitar Rumpon di Palabuhanratu. Jurnal Penelitian Perikanan Indonesia, 24(2), 117-128.

Sarianto, D., \& Istrianto, K. (2019). Sebaran Rumpon di Samudera Hindia pada Daerah Penangkapan Purse Seine. Jurnal Airaha, 8(02), 059-066.

Simbolon, D., Jeujanan, B., \& Wiyono, E. S. (2011). Efektivitas pemanfaatan rumpon pada operasi penangkapan ikan di Perairan Kei Kecil, Maluku Tenggara. Marine Fisheries: Journal of Marine Fisheries Technology and Management, 2(1), 1928.

Wudianto, W., Mahiswara, M., \& Linting, M. (2017). Pengaruh ukuran mata pancing rawai dasar terhadap hasil tangkapan. Jurnal Penelitian Perikanan Indonesia, $1(1), 58-67$. 